Prepared for the U.S. Department of Energy

under Contract DE-AC05-76RL01830

\title{
Offshore Wind Energy Permitting: A Survey of U.S. Project Developers
}

FB Van Cleve
AE Copping

November 2010

Pacific Northwest

NATIONAL LABORATORY

Proudly Operated by Battelle Since 1965 


\title{
DISCLAIMER
}

This report was prepared as an account of work sponsored by an agency of the United States Government. Neither the United States Government nor any agency thereof, nor Battelle Memorial Institute, nor any of their employees, makes any warranty, express or implied, or assumes any legal liability or responsibility for the accuracy, completeness, or usefulness of any information, apparatus, product, or process disclosed, or represents that its use would not infringe privately owned rights. Reference herein to any specific commercial product, process, or service by trade name, trademark, manufacturer, or otherwise does not necessarily constitute or imply its endorsement, recommendation, or favoring by the United States Government or any agency thereof, or Battelle Memorial Institute. The views and opinions of authors expressed herein do not necessarily state or reflect those of the United States Government or any agency thereof.

\author{
PACIFIC NORTHWEST NATIONAL LABORATORY \\ operated by \\ BATTELLE \\ for the \\ UNITED STATES DEPARTMENT OF ENERGY \\ under Contract DE-AC05-76RL01830 \\ Printed in the United States of America \\ Available to DOE and DOE contractors from the \\ Office of Scientific and Technical Information, \\ P.O. Box 62, Oak Ridge, TN 37831-0062; \\ ph: (865) 576-8401 \\ fax: (865) 576-5728 \\ email: reports@adonis.osti.gov \\ Available to the public from the National Technical Information Service, \\ U.S. Department of Commerce, 5285 Port Royal Rd., Springfield, VA 22161 \\ ph: (800) 553-6847 \\ fax: $(703) 605-6900$ \\ email: orders@ntis.fedworld.gov \\ online ordering: http://www.ntis.gov/ordering.htm
}

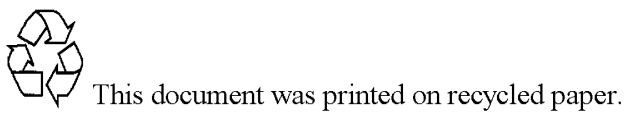

(9/2003) 


\section{Offshore Wind Energy Permitting: A Survey of U.S. Project Developers}

FB Van Cleve

AE Copping

November 2010

Prepared for

the U.S. Department of Energy

under Contract DE-AC05-76RL01830

Pacific Northwest National Laboratory

Richland, Washington 99352 


\section{Summary}

The U.S. Department of Energy (DOE) has adopted a goal to generate $20 \%$ of the nation's electricity from wind power by 2030 . Achieving this " $20 \%$ Wind Scenario" in 2030 requires acceleration of the current rate of wind project development. Offshore wind resources contribute substantially to the nation's wind resource, yet to date no offshore wind turbines have been installed in the U.S. Progress developing offshore wind projects has been slowed by technological challenges, uncertainties about impacts to the marine environment, siting and permitting challenges, and viewshed concerns.

To address challenges associated with siting and permitting, Pacific Northwest National Laboratory (PNNL) surveyed offshore wind project developers about siting and project development processes, their experience with the environmental permitting process, and the role of coastal and marine spatial planning (CMSP) in development of the offshore wind industry.

Based on the responses to survey questions, we identify several priority recommendations to support offshore wind development.

\section{Improve certainty associated with environmental permitting processes and requirements, and ensure appropriate application of regulations.}

- The current federal permitting process includes two NEPA reviews for a commercial lease competitively awarded. Developers are finding the EIS required for the Site Assessment Plan (the first of two EIS) problematic because it requires site data that have not yet been collected at this stage in the project development process. The Bureau of Ocean Energy Management, Regulation, and Enforcement (BOEMRE) should explore options to achieve sufficient environmental review with only one Environmental Impact Statement (EIS). Elimination of one EIS could shorten the permitting process by 1.5 years.

- Reduce uncertainty in the project permitting process by establishing and adhering to document review deadlines and providing clear and consistent instructions to developers. Interagency coordination on requirements and standards is critical for providing clear and consistent instructions. Reducing uncertainty associated with permitting will reduce overall project costs and time to permitting.

- Review permitting requirements and streamline permitting requirements if appropriate. Specifically, the U.S. Environmental Protection Agency should evaluate whether a Clean Air Act permit should be required to erect a meteorological tower, as it is not required to install a buoy to collect meteorological data.

- Guarantee development rights to developers if site investments are made (i.e. geotechnical or biological studies).

\section{Develop a process and implement collection of environmental data to meet national needs.}

- Baseline environmental knowledge gaps should be addressed in a strategic, coordinated fashion. Federal agencies should play a significant role in collecting or overseeing the 
collection of baseline environmental data of national interest. Collection of baseline environmental data is costly and time consuming to project developers; pre-existing data serve as a significant incentive to developers during site selection.

- Utilize Strategic Environmental Assessments (SEAs) to integrate environmental considerations and data for particular uses/programs (e.g., marine renewable) into policies at a regional or national level. SEA have been used in Europe (e.g., SEA for marine renewable in Scotland) and Canada (e.g., SEA for development of tidal test facilities in the Bay of Fundy) to facilitate the siting and development of pilot and commercial-scale marine energy projects. In the U.S., the SEA process is analogous to combining a programmatic Environmental Impact Statement (EIS) and project-specific EIS into a single effort.

\section{Ensure offshore wind energy interests are represented in CMSP}

- In order to engage meaningfully in CMSP, ocean energy proponents need to articulate their needs, limitations, and priority areas for consideration with other ocean uses. One reason this has not yet been done is because needs are diverse, especially if other forms of ocean energy (i.e. tidal, wave, or Ocean Thermal Energy Conversion) are considered. In spite of the challenge, this information will be critical to ensure that ocean energy is adequately considered in state, regional, and national CMSP.

- DOE should work to ensure that the nation's interest in renewable ocean energy is represented among priority interests such as production of seafood, safe marine transportation, national security, and environmental conservation.

- Regulatory agencies should look for opportunities to use the products of CMSP to meet regulation requirements imposed on project developers when possible.

In this report, we summarize findings, discuss the implications, and suggest actions to improve the permitting and siting process. 



\section{Acknowledgments}

We would like to thank the offshore wind developers who agreed to be interviewed for this survey. We appreciate the observations and ideas they shared with us as part of this project and their willingness to share their lessons learned and perceptions of barriers with readers of this report. This study was funded by the U.S. Department of Energy's Wind and Water Power Program. 


\section{Acronyms and Abbreviations}

BOEMRE - Bureau of Ocean Energy Management, Regulation, and Enforcement CMSP - Coastal and Marine Spatial Planning

DOE - U.S. Department of Energy

EIS - Environmental Impact Statement

NEPA - National Environmental Policy Act

NOAA - National Oceanic and Atmospheric Administration

PNNL - Pacific Northwest National Laboratory

PPA - Power Purchase Agreement

USACE - U.S. Army Corps of Engineers 


\section{Contents}

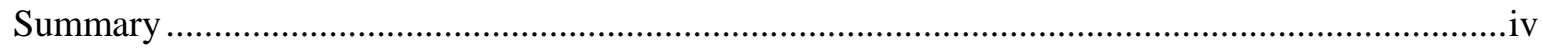

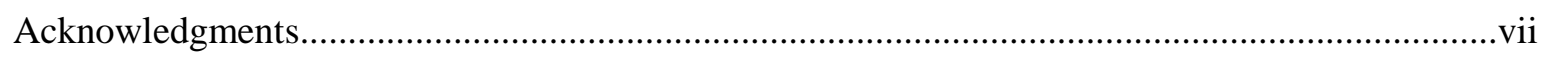

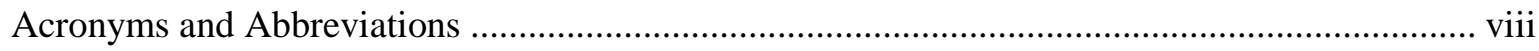

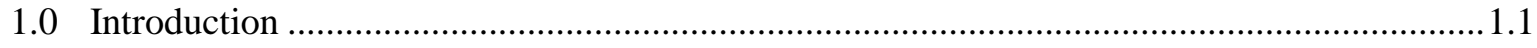

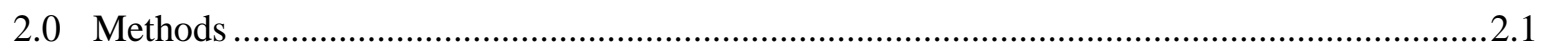

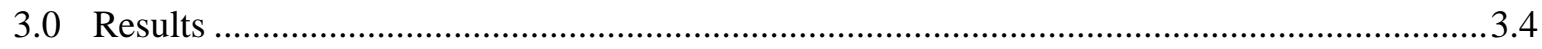

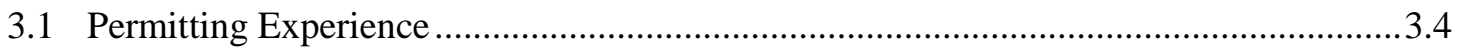

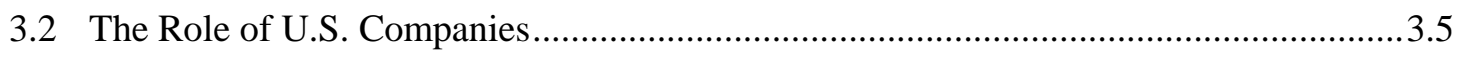

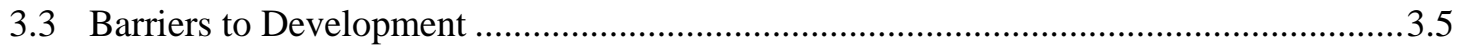

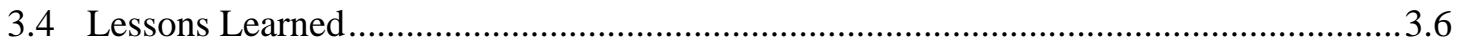

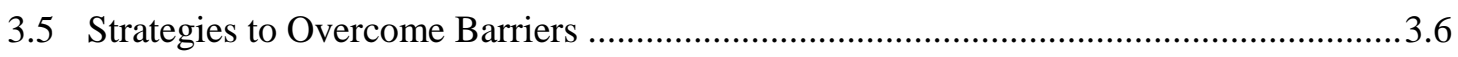

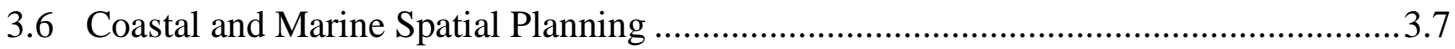

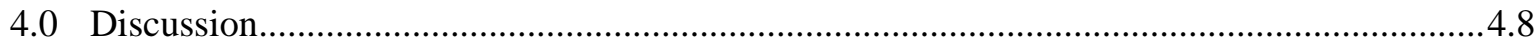

4.1 Strategies to Overcome Major Barriers .................................................................... 4.9

4.2 Coastal and Marine Spatial Planning …….................................................................. 4.11

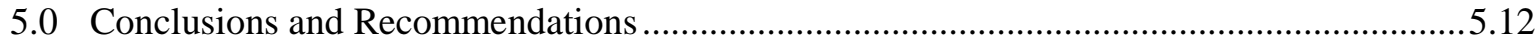

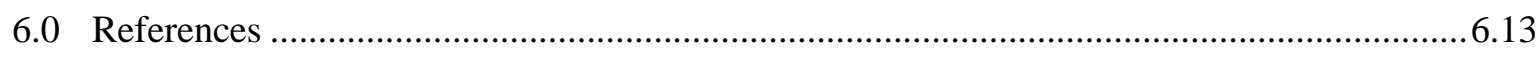

Appendix A . U.S. Offshore Wind Developers and Projects ....................................................... 1

\section{Table}

Table 1. Project summaries of offshore wind project developers surveyed.................................2.3 



\subsection{Introduction}

The U.S. Department of Energy (DOE) has adopted a goal to generate $20 \%$ of the nation's electricity from wind power by 2030. Achieving this " $20 \%$ Wind Scenario" in 2030 requires acceleration of the current rate of wind project development. Offshore wind resources contribute substantially to the nation's wind resource, yet to date no offshore wind turbines have been installed in the U.S. Progress developing offshore wind projects has been slowed by technological challenges, uncertainties about impacts to the marine environment, siting and permitting challenges, and viewshed concerns.

In order to address challenges, alleviate concerns, and reduce critical uncertainties, strategic information collection and stakeholder outreach must inform future Federal and industry investments. This information will be used to prioritize challenges, identify practical solutions, and document lessons learned. As a first step, Pacific Northwest National Laboratory (PNNL) surveyed offshore wind project developers about siting and project development processes, their experience with the environmental permitting process, and the role of coastal and marine spatial planning (CMSP) in development of the offshore wind industry. In this report, we summarize our findings, discuss the implications, and suggest actions to improve the permitting and siting process.

\subsection{Methods}

PNNL identified prospective U.S. offshore wind project developers and proposed projects in the U.S. using DOE data, recent news articles, and developer websites (Appendix A). Most projects identified are in very early stages of project development or at a conceptual stage. Selection criteria used for offshore wind developers participation in the surveys included:

- Project maturity/developer experience - Developers should have at least one project active in the federal or state permitting process

- Access and information availability - Information about the developer and project is publically available

- Developer willingness to participate - Developer is willing to be interviewed and to have interview results reflected in a publicly-available report

Because many developers in the U.S. are very early in the project development process, we targeted developers who have at least some experience with the permitting process. Although our focus was on developers with the most developed projects, we also thought it was valuable to get some breadth in perspective by including a municipality-scale developer and a Great Lakes developer. Developers are organized in Appendix A by how well they met the selection criteria (good alignment with criteria $=$ darker green background; fair $=$ lighter green, not aligned $=$ white) .

Ten offshore wind developers were contacted to participate in the survey; seven developers responded and were willing to participate (Table 1). Semi-structured interviews (Kvale 1996) were conducted by PNNL staff. The interviews focused on the siting and project development process, developers' experience with the environmental permitting process, and the role of coastal and marine spatial planning 
(CMSP) in development of the offshore wind industry. Interviews were conducted by phone and lasted approximately 30 minutes. Interview notes were typed, summarized, and analyzed for patterns. 
Table 1. Project summaries of offshore wind project developers surveyed.

\begin{tabular}{|c|c|c|c|c|c|c|c|c|}
\hline Developer & Project & Location & $\begin{array}{l}\text { Capacity } \\
\text { (MW) }\end{array}$ & $\begin{array}{c}\text { Distance } \\
\text { offshore / } \\
\text { water depth }\end{array}$ & $\begin{array}{c}\text { \# Turbines } \mathrm{X} \\
\text { model }\end{array}$ & $\begin{array}{l}\text { Commis- } \\
\text { sioned }\end{array}$ & $\begin{array}{l}\text { Purchasing } \\
\text { Utility }\end{array}$ & Status \\
\hline $\begin{array}{l}\text { Cape Wind } \\
\text { Associates, LLC }\end{array}$ & Cape Wind & $\begin{array}{l}\text { Nantucket } \\
\text { Sound, MA }\end{array}$ & $454 \mathrm{MW}$ & $5.2-13.8 \mathrm{mi}$ & $\begin{array}{l}130 \times 3.6 \mathrm{MW} \\
\text { Siemens }\end{array}$ & 2013 & National Grid & Lease agreement signed. \\
\hline Deepwater Wind & $\begin{array}{l}\text { P1: Block Island } \\
\text { Wind Farm Demo } \\
\text { P2: RI Sound } \\
\text { Wind Farm }\end{array}$ & $\begin{array}{l}\text { Block } \\
\text { Island, RI }\end{array}$ & $\begin{array}{l}\text { P1: } 28 \mathrm{MW} \\
\text { P2: } 385 \mathrm{MW}\end{array}$ & $\begin{array}{l}\text { P1: } 3 \mathrm{mi} \\
\text { P2: } 22 \mathrm{mi}\end{array}$ & $\begin{array}{l}\text { Phase 1: } 5-8 \\
\text { P2: } 100^{*}\end{array}$ & $\begin{array}{l}\text { P1: } 2012 \\
\text { P2:? }\end{array}$ & National Grid & $\begin{array}{l}\text { PPA currently appealed for } \\
\text { the second time. Awaiting } \\
\text { decision. }\end{array}$ \\
\hline $\begin{array}{l}\text { NRG Bluewater } \\
\text { Wind }\end{array}$ & $\begin{array}{l}\text { Bluewater Wind } \\
\text { Delaware }\end{array}$ & $\begin{array}{l}\text { Rehoboth } \\
\text { Beach, DL }\end{array}$ & $200 \mathrm{MW}$ & $13 \mathrm{mi}$ & $60-200^{*}$ & 2013 & $\begin{array}{l}\text { Delmarva } \\
\text { Power and } \\
\text { Light }\end{array}$ & $\begin{array}{l}\text { Commercial. Prelim. permit } \\
\text { secured; installing met tower. }\end{array}$ \\
\hline $\begin{array}{l}\text { NRG Bluewater } \\
\text { Wind }\end{array}$ & $\begin{array}{l}\text { Bluewater Wind } \\
\text { NJ }\end{array}$ & $\begin{array}{l}\text { Atlantic } \\
\text { City }\end{array}$ & $350 \mathrm{MW}$ & $16.5 \mathrm{mi}$ & $\mathrm{N}-\mathrm{A} \dagger$ & $\begin{array}{l}2013- \\
2014 \text { for } \\
\text { DE site }\end{array}$ & $\mathrm{N}-\mathrm{A}$ & $\begin{array}{l}\text { Have interim leases for met } \\
\text { towers of DE and NJ and will } \\
\text { install towers next year }\end{array}$ \\
\hline $\begin{array}{l}\text { Fisherman's } \\
\text { Energy }\end{array}$ & FERN Wind Farm & $\begin{array}{l}\text { Atlantic } \\
\text { City, NJ }\end{array}$ & $\begin{array}{l}\text { P1: } 20 \mathrm{MW} \\
\text { P2: } 350 \mathrm{MW}\end{array}$ & $\begin{array}{l}\mathrm{P} 1: 2.8 \\
\mathrm{mi} / 40 \mathrm{ft} \\
\mathrm{P} 2: 10-12 \\
\mathrm{mi}\end{array}$ & $\begin{array}{l}\text { P1: } 6 \mathrm{x} \\
\text { undecided } \\
\text { P2: } 66^{*}\end{array}$ & $\begin{array}{l}\text { P1: 2011- } \\
\text { 2012 } \\
\text { P2: 2014* }\end{array}$ & N-A & $\begin{array}{l}\text { Met buoy launched April, } \\
2010 \text { at further offshore site. } \\
\text { Pre-installation monitoring } \\
\text { and testing }\end{array}$ \\
\hline Town of Hull & $\begin{array}{l}\text { Hull Municipal } \\
\text { Light Plant } \\
\text { Demonstration } \\
\text { Project }\end{array}$ & Hull, MA & $14 \mathrm{MW}$ & $\begin{array}{l}1.5 \mathrm{mi}^{*} / 40- \\
50 \mathrm{ft}\end{array}$ & $\begin{array}{l}4 \text { x Siemens } \\
\text { likely }\end{array}$ & $2013+^{*}$ & Town of Hull & $\begin{array}{l}\text { Evaluating funding options } \\
\text { for } 20 \% \text { match to } \$ 1 \mathrm{M} \\
\text { earmark. }\end{array}$ \\
\hline $\begin{array}{l}\text { Garden State } \\
\text { Offshore Energy } \\
\text { (Deepwater Wind } \\
\text { and Public Service } \\
\text { Electric and Gas) }\end{array}$ & $\begin{array}{l}\text { Garden State } \\
\text { Offshore Energy }\end{array}$ & $\begin{array}{l}\text { Ocean } \\
\text { City, NJ }\end{array}$ & $350 \mathrm{MW}$ & $\begin{array}{l}16-20 \\
\mathrm{mi} / 100 \mathrm{ft}^{*}\end{array}$ & $\begin{array}{l}96 \times \\
\text { undecided }\end{array}$ & $\begin{array}{l}2015- \\
2016\end{array}$ & $\begin{array}{l}\text { Public Service } \\
\text { Electric and } \\
\text { Gas }\end{array}$ & $\begin{array}{l}\text { Awarded exploratory lease, } \\
\text { completed geotechnical } \\
\text { work, ecology study of site. } \\
\text { Met buoy installation } \\
\text { expected next year. Buoy } \\
\text { undergoing validation in RI. }\end{array}$ \\
\hline $\begin{array}{l}\text { JW Great Lakes } \\
\text { Wind/Cuyahoga } \\
\text { County }\end{array}$ & $\begin{array}{l}\text { Great Lakes Wind } \\
\text { Energy Center }\end{array}$ & $\begin{array}{l}\text { Lake Erie, } \\
\text { OH }\end{array}$ & $20^{*}$ & $3 \mathrm{mi}^{*}$ & $3-7^{*}$ & $\mathrm{~N}-\mathrm{A}$ & N-A & $\begin{array}{l}\text { Completed feasibility study } \\
\text { in 2009. Issuing RFP for } \\
\text { avian and bat ecological } \\
\text { studies. Lake Erie } \\
\text { Development Corp. is new } \\
\text { developer. }\end{array}$ \\
\hline
\end{tabular}

${ }^{*}$ Unconfirmed or updates not available; may reflect outdated information. $\uparrow \mathrm{N}-\mathrm{A}=$ Not Available. 


\subsection{Results}

We surveyed seven offshore wind developers, including one Great Lakes developer and one municipal-scale developer. Of the seven developers we surveyed, only one (Cape Wind) had completed the environmental permitting process. The remaining six companies were at early stages in the permitting process. Fishermen's Energy, Great Lakes Wind, Town of Hull, and Deepwater Wind are all working to develop projects in state waters (New Jersey, Ohio, Massachusetts, and Rhode Island, respectively). Garden State Energy, NRG Bluewater Wind, and Cape Wind are developing projects in federal waters and two developers, Fishermen's Energy and Deepwater, are planning projects both in state and federal waters.

\subsection{Permitting Experience}

Developers reported that experience with offshore wind project permitting was "fairly painful", "extremely challenging", "overly arduous", "relative easy because it's in state waters", "uncertain and unnecessarily slow", and "poorly defined resulting in unnecessarily large investment risk because sites can't be secured". Developers reported a disconnect between support at the top of Bureau of Ocean Energy Management, Regulation, and Enforcement (BOEMRE; formerly Minerals Management Service) and slowing of progress to a standstill at the permit processing level within agencies, shifting requirements ("we saw goalposts move constantly"), and that "state permitting is relatively straight forward and easy [compared to the federal process]".

Developers noted that clear instructions from agencies were often lacking as many state or federal agencies are developing a permitting process at the same time they are trying to permit the first wave of projects. Developers also noted a lack of deadlines and review timelines for response from federal agencies and expressed frustration with this additional uncertainty. ${ }^{1}$ Generally, developers working at the state level, in various states, expressed less discontent with the permitting process. Frustration with the federal permitting process was common to all respondents working at the federal level.

Permitting requirements that appear to be inconsistent are also frustrating developers. One example is that an air quality permit under the Clean Air Act is required to erect a meteorological (met) tower, but not to install a buoy also used to collect meteorological data. There is concern that lenders will not accept data collected with a meteorological buoy, which has stopped some developers from choosing this more streamlined data collection option.

Developers working in federal waters expressed strong concern about the requirement (for commercial leases issued competitively) that both the Site Assessment Plan and Construction and Operations Plan undergo NEPA review (i.e. each requires an Environmental Impact Statement (EIS) under NEPA). ${ }^{1}$ Each EIS takes 18 months to complete. Developers are finding the Site Assessment Plan (the first of the two EIS) problematic because it requires site assessment data, which would not yet have been collected at this stage in the project development process.

\footnotetext{
${ }^{1}$ This comment is similar to those received by BOEM during the public review of the Renewable Energy and Alternate Uses of Existing Facilities o the Outer Continental Shelf rule (Federal Register 2009).
} 


\subsection{The Role of U.S. Companies}

Four respondents addressed the role of U.S. manufacturing or service companies in offshore wind development. This role was compared to that of European companies, widely recognized as industry leaders. Paraphrased responses included:

- It's important to work with companies who have experience in this industry (i.e. Europeans), but there are some areas where U.S. companies also have significant experience working in the offshore environment, such as engineering, installation, service support, and environmental permitting support. More capacity will likely develop as project developer demand increases and as projects become more developed.

- The most promising areas for U.S. companies to get into at this stage are shipbuilding and turbine installation. I'm also hopeful that there will be turbine manufacturing in the U.S. soon if there is a U.S. market.

- To catch up to the European industry, it would take a federal government commitment similar to what they've seen in the UK with the three rounds of development. And we'd need a similar level of financial incentives too.

- What we need is just not available in the U.S. We're looking to buy American for the installation vessel, but otherwise we're making the best decision for the project [which means looking to Europe].

- What would it take to use U.S. service or manufacturing companies? Price is the single biggest factor for us.

\subsection{Barriers to Development}

Developers discussed several barriers to developing wind projects offshore. Of the six developers who addressed barriers, all cited an uncertain and arduous permitting process as a major barrier to development. Five mentioned access to capital as a major barrier while one developer said access to capital was a secondary concern and surmountable. One developer mentioned the need for technological developments and innovation while two mentioned challenges associated with gaining public acceptance through outreach activities, and the ability of the public to delay projects through the NEPA process. Others mentioned the need to get permitting agencies up to speed and comfortable with offshore development, and the pure logistical challenge of managing and orchestrating the timing of the development process for offshore projects.

While most developers were unable to estimate the cost associated with environmental permitting due to high uncertainty about the process, some cited the cost of specific studies or estimated that the permitting costs would be significant without defining the term. One developer estimated that $\$ 2$ - 3 million would be the cost for all the required environmental studies, citing the extreme cost of working in the offshore environment (weather downtime and safety procedures, etc). 


\subsection{Lessons Learned}

Respondents were asked to reflect on their project development process thus far and summarize what about their approach or someone else's approach had worked well. Some lessons learned, paraphrased from respondents, include:

- $\quad$ New Jersey's Offshore Wind Economic Development Act (A2873, passed August 19, 2010) sets up an alternative revenue stream to Power Purchase Agreements (PPAs) including financial assistance and tax credits. New Jersey has also dedicated millions to support development of the offshore wind industry off its coast.

- Experience in the marine domain as offshore vessel operators and deep roots in the maritime and NJ business community has worked well for us. We've developed a very practical solution that consists of (1) developing in state waters where there is a clear regulatory process, (2) building at the right scale (i.e. starting small), (3) benefiting from baseline ecological data that had already been collected by the state, and (4) favorable state incentives and policies that allow for an incremental, 'learn-as-you-go' approach (i.e. deploy and monitor).

- Having a PPA has been really important for us. Also, engaging with agencies early and often in order to get issues and concerns out on the table so that we can be responsive rather than having to guess at concerns.

- Throughout the feasibility study, progress was slow, but there was no community backlash because we didn't propose too much too fast.

- The project is very community-based with lots of local support. It's seen as an economic development and tourism opportunity for the town.

- Agility is important. We're a small company and being able to move and respond quickly has served us well.

\subsection{Strategies to Overcome Barriers}

Reflecting on barriers cited and lessons learned about what had worked well, respondents were asked to summarize strategies to overcome barriers. Paraphrased strategies from respondents include:

- Establish a conflict-of-interest-free pathway to educate the regulatory agencies about the offshore environment, wind turbine technology, and support their decision making with information specific to offshore wind energy technologies and the characteristics of offshore wind sites. Developers are responsible for providing the regulatory agencies with information, but as project proponents they are not in a position to provide the needed broad education to agencies. That's a role the National Laboratories could play. 
- Developers need (1) revenue certainty either through a PPA or other dedicated revenue stream and (2) certainty in the federal permitting process, including MOUs between federal permitting agencies outlining and aligning permitting requirements and standards. ${ }^{2}$

- A phased approach to development will be necessary to get to the President's renewable energy goals (i.e. produce 10\% of U.S. electricity from renewable sources by 2012 and $25 \%$ by 2025). The phased approach has to include responsible development and post-installation monitoring. We can't afford [as a nation] to study the ecosystem to death.

- Developers and agencies should rely more on environmental effects data from Europe and not require that all these studies be repeated here in the U.S.

- A mechanism to protect developers' investment in offshore sites is necessary. The current system provides no assurances that investment in the form of site studies (geotechnical, meteorological, biological, etc.) will be protected. ${ }^{2}$

- We need to know where we can go and where we can't. The government should delineate areas for development or open development while guaranteeing development rights if site investments are made.

- Clarify and streamline permitting process and shorten the current timeline of 7-9 years. Specifically, BOEMRE should consolidate NEPA requirements so that only one EIS is required. Strategic Environmental Assessments have worked well in Europe to support a more streamlined permitting process.

- The role of National Oceanic and Atmospheric Administration (NOAA) Fisheries should be to do more systematic, baseline ecological assessments offshore.

- Provide information and technical educational opportunities to BOEMRE to support permitting work.

- Federal agencies need to set and keep review deadlines. State agencies are better at having deadlines, but we found that for federal permits deadlines often don't exist. Deadlines are important so that developers know what to expect and can plan accordingly.

- Public acceptance is overcome with time and groundwork.

\subsection{Coastal and Marine Spatial Planning}

Finally, developers were asked to share their views on Coastal and Marine Spatial Planning (CMSP). Specifically, developers were asked to comment on the value of CMSP or concerns they have about the process or outcomes as they understand them. Respondents discussed CMSP at the federal level and also state level in some cases (i.e. RI, MA). Most respondents were familiar with state (if applicable) and federal CMSP efforts, and, while some expressed support and some expressed concern for these efforts,

\footnotetext{
${ }^{2}$ This comment is similar to those received by BOEM during the public review of the Renewable Energy and Alternate Uses of Existing Facilities o the Outer Continental Shelf rule (Federal Register 2009).
} 
all discussed the need to bound or define CMSP (i.e. what is it and what is it not; what do we expect it to do and what actions are outside of the CMSP process) to reduce uncertainties associated with the process and outcomes.

Four respondents expressed concern that CMSP would delay progress in the industry and potentially hold up individual projects. Those respondents pointed out that offshore renewable energy development is already a 7-9 year process and further delay would be untenable. They also noted that CMSP is an extensive and multi-year activity and that it should not be necessary to halt offshore wind energy development progress during CMSP efforts.

Three respondents expressed concern that, because renewable ocean energy is an emerging ocean use, the industry would be allocated remaining ocean space following allocations to all traditional (i.e. fishing, shipping) uses. The concern is the same for all other ocean uses: not every area is equally valuable for a specific use. The offshore wind industry is concerned that ocean space not "claimed" by traditional users may not coincide with acceptable wind resources or commercially feasible distance from shore or sea floor conditions. Respondents argued that such an outcome would not serve the national renewable energy agenda.

Three developers were very positive about CMSP, as long as CMSP does not slow down offshore wind development or relegate the industry to undesirable sites, and cited positive experiences with state marine spatial planning efforts. They valued access to ocean data and CMSP as a mechanism to avoid spatial conflicts with other ocean users. One respondent expressed strong opposition to CMSP as proposed, mainly over concern that CMSP will take areas away from traditional users (fishermen, specifically) and slow down the ocean energy development process. The respondent's suggestion was that Fishery Management Councils act as the regional CMSP bodies and that negative impacts of new uses on traditional ocean uses should be mitigated considering cumulative impacts to fisheries.

Most developers expressed fear that CMSP could introduce additional layers of regulation. Most also noted that, from the perspective of developers, CMSP may add complications to an already lengthy siting and permitting process, while not promising to streamline or assist in siting to a great extent.

\subsection{Discussion}

No company in the U.S. is able to reflect on their experience securing environmental permits and provide an after-the-fact assessment of the entire current permitting process; Cape Wind is the only company to have completed the permitting process to date and their experience does not mirror the current BOEMRE-lead process as they were grandfathered into the U.S. Army Corps of Engineers (USACE)-lead process (i.e. Pre-Environmental Policy Act). However, all companies surveyed had experience with the BOEMRE-lead permitting process to share, gained directly or vicariously. It is widely recognized that the regulatory trail was blazed by Cape Wind as federal agencies and Congress determined how to permit offshore renewable energy development. However, contrary to what some had hoped, the expected permitting timeline for the next wave of projects is effectively no shorter than Cape Wind's 9 year process. In spite of having designated a new lead agency and developed a new permitting process, the current permitting process remains 7-9 years - comparable to that of a nuclear power plant. 
It is not surprising that some developers characterize the environmental permitting process as arduous, slow, and challenging. What we found surprising, however, was that this description mostly applied to the permitting process for projects in federal waters and not in state waters. Some of the comments developers shared applied to both federal and state processes: the regulatory process is new, being developed and implemented simultaneously, and agency staff at federal and state regulatory agencies are working through a long learning curve on the technical details of a new industry. Even though states are struggling to come up with permitting processes and federal permits are still required in state waters from the USACE and the Environmental Protection Agency, permitting within state waters generated much less criticism from developers than permitting in federal waters.

BOEMRE was the focus of much of the criticism of the federal permitting process. Respondents expressed frustration that permitting delays continue even now that a permitting pathway has been developed. Respondents attributed the delay generally to a lack of agency knowledge about the offshore wind industry, prospective sites, and associated risks. For example, respondents perceived BOEMRE to be adapting their experience with offshore oil and gas rather than using nearly two decades of experience with offshore wind energy in Europe to address lingering uncertainties. Respondents also perceived the BOEMRE process to be opaque. Several developers recounted their experience struggling with undefined terms and long response times. Developers seem to be most crippled by the uncertainty in the federal permitting process rather than its length.

\subsection{Strategies to Overcome Major Barriers}

An uncertain and arduous permitting process and access to capital are the biggest barriers to development of an offshore wind industry according to our survey of developers. "Uncertainty" refers to lack of clear information about environmental permitting requirements, timelines, and deadlines as well as uncertainty in the form of risk taken on by project developers to invest in site studies without secured development rights. Like other barriers discussed below, uncertainty has a direct and significant impact on project costs. "Arduousness" refers primarily to permitting requirements considered by developers to be unnecessary or excessive. Suggestions to reduce uncertainty associated with permitting and siting:

- Create favorable development policies at the state and federal level. For example, New Jersey has passed regulations establishing financial assistance to offshore wind developers and has dedicated millions of dollars for site assessments and assistance.

- Develop clear permitting pathways and deadlines for review processes. Federal agencies should set and adhere to review deadlines. Deadlines are important so that developers know what to expect and can plan accordingly.

- Interagency coordination through MOUs outlining and aligning permitting requirements and standards is needed.

- Delineate ocean areas to be avoided and areas open to development.

- Guarantee development rights if site investments are made in the form of site studies (geotechnical, meteorological, biological, etc.) to reduce overall risk associated with offshore development. 
Suggestions for making the permitting process less arduous include:

- Clarify and streamline permitting process and shorten the current timeline of 7-9 years. Specifically, BOEMRE should consolidate NEPA requirements so that only one EIS is required. ${ }^{3}$ Suggestions include conducting a regional EIS or Environmental Assessment to satisfy the NEPA requirements for the Site Assessment Plan or using state spatial planning activities to satisfy NEPA requirements. Strategic Environmental Assessments have worked well in Europe to support a more streamlined permitting process.

- Consistent application of federal laws. Suggestions include reevaluating the requirement for a Clean Air Act permit to install a met tower.

- Developers and agencies should rely more on environmental effects data from Europe and avoid repeating studies when it is not necessary to conduct the research in U.S. waters.

- NOAA Fisheries should be involved in systematic, baseline ecological assessments offshore.

- A phased approach to development will be necessary to get to the President's renewable energy goals (i.e. produce 10\% of U.S. electricity from renewable sources by 2012 and $25 \%$ by 2025). The phased approach has to include responsible development and post-installation monitoring.

Although this study did not explicitly focus on addressing financial issues, suggestions to facilitate overcoming capital issues include:

- Support revenue certainty through facilitation of secure power markets (i.e. PPAs or other dedicated revenue streams such as Renewable Obligation Certificates used in the UK)

- Ensure financial incentives (assistance, loans, or tax credits) are available to facilitate investment in offshore wind.

Public acceptance was cited, although not universally, as a major barrier among developers surveyed. Developers discussed challenges associated with both demonstration and commercial scale wind farms. Suggestions to promote public acceptance include:

- Move projects forward at a slow pace in order to avoid community backlash.

- Public acceptance can be overcome with time and groundwork.

\footnotetext{
${ }^{3}$ In response to public comments received during the process of finalizing the Renewable Energy and Alternate Uses of Existing Facilities on the Outer Continental Shelf rule, BOEMRE combined the Site Assessment Plan and lease sale into one activity, which reduced the number of NEPA reviews from three to two (i.e one for the Site Assessment Plan/lease sale and one for the Construction and Operations Plan). BOEMRE currently requires two NEPA reviews for commercial leases issued competitively to reflect two distinct phases of development as defined by BOEMRE: (1) sites assessment phase, and (2) generation of power phase. Only one NEPA review is required for limited leases. In an effort to reduce the review time for commercial leases, BOEMRE also eliminated the need for BOEMRE approval of site surveys, which can be permitted under USACE's Nationwide Permit program (Federal Register 2009).
} 
Lack of agency knowledge about offshore wind energy generation was cited as a barrier. Suggestions to overcome knowledge barriers include:

- Provide information and technical educational opportunities to BOEMRE to support permitting work. National Laboratories are well positioned to provide this function.

Technological developments are also needed to accommodate offshore conditions, such as seabed conditions, deep water siting, and storm conditions, and to mitigate for environmental impacts. There were no specific suggestions about strategies to overcome technological barriers.

Finally, developers listed several other attributes that had been helpful in their successful progress including experience in the marine domain, agility and flexibility as a company for fast response, carefully selecting a manageable project size, and existing baseline ecological site data. They also said that they had had success engaging agencies early and often to anticipate issues/concerns.

Although an offshore wind industry is becoming more established in the U.S., resources, processes, and incentives available pale in comparison to financial incentives, permitting systems, and investment guarantees made available in Europe. U.S. capabilities to support an offshore wind industry include ship building, marine engineering, offshore service s and support, and environmental permitting. Development of a U.S. based manufacturing industry would require a significant market for turbines and offshore wind power in the U.S.

\subsection{Coastal and Marine Spatial Planning}

In contrast to practices throughout the last century, ocean space and resources are no longer considered vast and limitless. On the contrary, the emergence of a nascent ocean energy industry in the U.S. has traditional and new ocean users concerned about crowded coastal environments and incompatible uses competing for marine territory. CMSP has gained momentum in the U.S. largely from the emerging need to understand ocean activities and then to make strategic decisions about the use of limited ocean space. Offshore wind developers are very apprehensive about CMSP because there is a sense that, as the "emerging" ocean use, they'll be allocated ocean space after all other existing uses. Because not all ocean areas are equally economically desirable, offshore wind developers fear they will be allocated undesirable ocean areas where development of projects will be less profitable or not feasible; developers expressed little confidence that development of an offshore renewable energy industry would receive treatment equal to traditional ocean uses.

The compromises required to plan for the orderly use of ocean resources is sometimes responsible for making CMSP unpopular among ocean users. CMSP, the concept and the process, is nebulous, broad, and comprehensive, making it difficult to understand what CMSP is and what it is not. Offshore wind developers are eager for permitting and siting certainty, but dread development of new restrictions on technologies or sites. The timeline(s) for implementing CMSP are also far from clear; CMSP is a multiyear planning process. Offshore developers currently developing projects cannot afford to wait until spatial plans are complete to proceed with project development. Thus, CMSP introduces new uncertainty for developers of current projects, but will likely increase certainty for future developers, assuming CMSP proceeds as planned nationally and regionally. 
While most developers we surveyed acknowledge the need for CMSP, the process is viewed by current offshore wind developers primarily as an additional layer of complication, regulation, time, and limitation to the offshore wind development process. At this time, most developers surveyed do not see major benefits to the offshore wind energy industry from CMSP although they acknowledge the utility in avoiding use conflicts and the possibility of gaining geospatial ocean data through the process.

\subsection{Conclusions and Recommendations}

Based on strategies identified by developers to overcome major barriers to offshore wind development in the U.S., we identify several priority recommendations to support offshore wind development. Recommendations also include considerations for developing supporting industries in the U.S. and how to use CMSP to appropriately consider ocean energy among existing ocean uses.

\section{Improve certainty associated with environmental permitting processes and requirements,} and ensure appropriate application of regulations.

- Explore options to achieve sufficient environmental review with only one EIS. Elimination of one EIS could shorten the permitting process by 1.5 years. Developers are finding the EIS required for the Site Assessment Plan (the first of two EIS) problematic because it requires site data that have not yet been collected at this stage in the project development process. BOEMRE may be considering conducting an Environmental Assessment for east coast regions to take the place of the first required EIS. CMSP activities could support the development of this Environmental Assessment.

- Reduce uncertainty in the project permitting process by establishing and adhering to document review deadlines and providing clear and consistent instructions to developers. Interagency coordination on requirements and standards is critical for providing clear and consistent instructions. Reducing uncertainty associated with permitting will reduce overall project costs and time to permitting.

- Review permitting requirements and streamline permitting requirements if appropriate. Specifically, the U.S. Environmental Protection Agency should evaluate whether a Clean Air Act permit should be required to erect a met tower, as it is not required to install a buoy to collect meteorological data.

- Guarantee development rights in sites if site investments are made (i.e. geotechnical or biological studies).

2. Develop a process and implement collection of environmental data to meet national needs.

- Baseline environmental knowledge gaps should be addressed in a strategic, coordinated fashion. Federal agencies should play a significant role in collecting or overseeing the collection of baseline environmental data of national interest. Collection of baseline environmental data is costly and time consuming to project developers; pre-existing data serve as a significant incentive to developers during site selection. 
- Utilize Strategic Environmental Assessments (SEAs) to integrate environmental considerations and data for particular uses/programs (e.g., marine renewable) into policies at a regional or national level. SEA have been used in Europe (e.g., SEA for marine renewable in Scotland) and Canada (e.g., SEA for development of tidal test facilities in the Bay of Fundy) to facilitate the siting and development of pilot and commercial-scale marine energy projects. In the U.S., the SEA process is analogous to combining a programmatic Environmental Impact Statement (EIS) and project-specific EIS into a single effort.

\section{Ensure offshore wind energy interests are represented in CMSP}

- In order to engage meaningfully in CMSP, ocean energy proponents need to articulate their needs, limitations, and priority areas for consideration with other ocean uses. One reason this has not yet been done is because needs are diverse, especially if other forms of ocean energy (i.e. tidal, wave, or OTEC) are considered. In spite of the challenge, this information will be critical to ensure that ocean energy is adequately considered in state, regional, and national CMSP.

- DOE should ensure that the nation's interest in renewable ocean energy is represented among priority interests such as production of seafood, safe marine transportation, national security, and environmental conservation.

- Regulatory agencies should look for opportunities to use the products of CMSP to meet regulation requirements imposed on project developers when possible.

\subsection{References}

Kvale, S. (1996). InterViews: An Introduction to Qualitative Research Interviewing. Thousand Oaks, CA: Sage Publications

Federal Register (2009). Volume 74, number. 81, April 29, 2009. National Archives and Records Administration 

Appendix A. U.S. Offshore Wind Developers and Projects 


\section{Appendix A}

Table of U.S. offshore wind developers and projects. Row colors indicate degree to which developers met selection criteria (good alignment with criteria $=$ darker green background; fair $=$ lighter green, not aligned $=$ white) .

\begin{tabular}{|c|c|c|c|c|c|c|c|c|}
\hline Developer & Project & Location & $\begin{array}{l}\text { Capacity } \\
\text { (MW) }\end{array}$ & $\begin{array}{c}\text { Distance } \\
\text { offshore / } \\
\text { water depth }\end{array}$ & $\begin{array}{c}\text { \# Turbines X } \\
\text { model }\end{array}$ & $\begin{array}{l}\text { Commis- } \\
\text { sioned }\end{array}$ & $\begin{array}{l}\text { Purchasing } \\
\text { Utility }\end{array}$ & Status \\
\hline $\begin{array}{l}\text { Cape Wind } \\
\text { Associates, LLC }\end{array}$ & Cape Wind & $\begin{array}{l}\text { Nantucket } \\
\text { Sound, MA }\end{array}$ & $454 \mathrm{MW}$ & $5.2-13.8 \mathrm{mi}$ & $\begin{array}{c}130 \times 3.6 \mathrm{MW} \\
\text { Siemens }\end{array}$ & 2013 & National Grid & $\begin{array}{l}\text { Lease agreement } \\
\text { signed. }\end{array}$ \\
\hline Deepwater Wind & $\begin{array}{l}\text { P1: Block Island } \\
\text { Wind Farm } \\
\text { Demo } \\
\text { P2: RI Sound } \\
\text { Wind Farm }\end{array}$ & $\begin{array}{l}\text { Block } \\
\text { Island, RI }\end{array}$ & $\begin{array}{l}\text { P1: 28MW } \\
\text { P2: } 385 \mathrm{MW}\end{array}$ & $\begin{array}{l}\text { P1: } 3 \mathrm{mi} \\
\text { P2: } 22 \mathrm{mi}\end{array}$ & $\begin{array}{l}\text { Phase 1: } 5-8 \\
\text { P2: } 100^{*}\end{array}$ & $\begin{array}{l}\text { P1: } 2012 \\
\text { P2: N-A† }\end{array}$ & National Grid & $\begin{array}{l}\text { PPA currently } \\
\text { appealed for the } \\
\text { second time. } \\
\text { Awaiting decision. }\end{array}$ \\
\hline $\begin{array}{l}\text { NRG Bluewater } \\
\text { Wind }\end{array}$ & $\begin{array}{l}\text { Bluewater Wind } \\
\text { Delaware }\end{array}$ & $\begin{array}{l}\text { Rehoboth } \\
\text { Beach, DL }\end{array}$ & $200 \mathrm{MW}$ & $13 \mathrm{mi}$ & $60-200^{*}$ & 2013 & $\begin{array}{l}\text { Delmarva } \\
\text { Power and } \\
\text { Light }\end{array}$ & $\begin{array}{l}\text { Commercial. Prelim. } \\
\text { permit secured; } \\
\text { installing met tower. }\end{array}$ \\
\hline $\begin{array}{l}\text { NRG Bluewater } \\
\text { Wind }\end{array}$ & $\begin{array}{l}\text { Bluewater Wind } \\
\text { NJ }\end{array}$ & $\begin{array}{l}\text { Atlantic } \\
\text { City, NJ }\end{array}$ & $350 \mathrm{MW}$ & $16.5 \mathrm{mi}$ & $\mathrm{N}-\mathrm{A}$ & $\begin{array}{l}2013-2014 \\
\text { for DE site }\end{array}$ & $\mathrm{N}-\mathrm{A}$ & $\begin{array}{l}\text { Have interim leases } \\
\text { for met towers of DE } \\
\text { and NJ and will install } \\
\text { towers next year }\end{array}$ \\
\hline $\begin{array}{l}\text { Fisherman's } \\
\text { Energy }\end{array}$ & $\begin{array}{l}\text { FERN Wind } \\
\text { Farm }\end{array}$ & $\begin{array}{l}\text { Atlantic } \\
\text { City, NJ }\end{array}$ & $\begin{array}{l}\text { P1: 20MW } \\
\text { P2: 350MW }\end{array}$ & $\begin{array}{l}\mathrm{P} 1: 2.8 \\
\mathrm{mi} / 40 \mathrm{ft} \\
\mathrm{P} 2: 10-12 \\
\mathrm{mi}\end{array}$ & $\begin{array}{l}\text { P1: } 6 x \\
\text { undecided } \\
\text { P2: } 66^{*}\end{array}$ & $\begin{array}{l}\text { P1: 2011- } \\
\text { 2012 } \\
\text { P2: } 2014^{*}\end{array}$ & $\mathrm{~N}-\mathrm{A}$ & $\begin{array}{l}\text { Met buoy launched } \\
\text { April, } 2010 \text { at further } \\
\text { offshore site. Pre- } \\
\text { installation monitoring } \\
\text { and testing }\end{array}$ \\
\hline $\begin{array}{l}\text { Wind Energy } \\
\text { Systems } \\
\text { Technology, Inc } \\
\text { (WEST) }\end{array}$ & Galveston sites & $\begin{array}{l}\text { Galveston, } \\
\text { TX }\end{array}$ & $150 \mathrm{MW}^{*}$ & $9 \mathrm{mi} / 55 \mathrm{ft}^{1}$ & $63^{*}$ & $\mathrm{~N}-\mathrm{A}$ & $\mathrm{N}-\mathrm{A}$ & $\begin{array}{l}\text { Met tower installed } \\
\text { and operating }\end{array}$ \\
\hline Town of Hull & $\begin{array}{l}\text { Hull Municipal } \\
\text { Light Plant } \\
\text { Demonstration } \\
\text { Project }\end{array}$ & Hull, MA & $14 \mathrm{MW}$ & $\begin{array}{l}1.5 \mathrm{mi}^{*} / 40- \\
50 \mathrm{ft}\end{array}$ & $\begin{array}{l}4 \text { x Siemens } \\
\text { likely }\end{array}$ & $2013+^{*}$ & Town of Hull & $\begin{array}{l}\text { Evaluating funding } \\
\text { options for } 20 \% \text { match } \\
\text { to } \$ 1 \mathrm{M} \text { earmark. }\end{array}$ \\
\hline $\begin{array}{l}\text { Garden State } \\
\text { Offshore Energy } \\
\text { (Deepwater Wind }\end{array}$ & $\begin{array}{l}\text { Garden State } \\
\text { Offshore Energy }\end{array}$ & $\begin{array}{l}\text { Ocean City, } \\
\text { NJ }\end{array}$ & $350 \mathrm{MW}$ & $\begin{array}{l}16-20 \\
\mathrm{mi} / 100 \mathrm{ft}^{*}\end{array}$ & $\begin{array}{l}96 \mathrm{x} \\
\text { undecided }\end{array}$ & $2015-2016$ & $\begin{array}{l}\text { Public Service } \\
\text { Electric and } \\
\text { Gas }\end{array}$ & $\begin{array}{l}\text { Awarded exploratory } \\
\text { BOEMRE lease, } \\
\text { completed }\end{array}$ \\
\hline
\end{tabular}




\begin{tabular}{|c|c|c|c|c|c|c|c|c|}
\hline $\begin{array}{l}\text { and Public } \\
\text { Service Electric } \\
\text { and Gas) }\end{array}$ & & & & & & & & $\begin{array}{l}\text { geotechnical work, } \\
\text { ecology study of site. } \\
\text { Met buoy installation } \\
\text { expected next year. } \\
\text { Buoy undergoing } \\
\text { validation in RI. }\end{array}$ \\
\hline $\begin{array}{l}\text { Southern } \\
\text { Company }\end{array}$ & $\begin{array}{l}\text { Southern Winds } \\
\text { Study }\end{array}$ & $\begin{array}{l}\text { Savannah, } \\
\text { GA }\end{array}$ & $10 \mathrm{MW}^{*}$ & $\mathrm{~N}-\mathrm{A}$ & $3-5^{*}$ & $\mathrm{~N}-\mathrm{A}$ & $\mathrm{N}-\mathrm{A}$ & $\begin{array}{l}\text { Awarded } 3 \text { limited } \\
\text { leases from MMS }\end{array}$ \\
\hline $\begin{array}{l}\text { JW Great Lakes } \\
\text { Wind/Cuyahoga } \\
\text { County }\end{array}$ & $\begin{array}{l}\text { Great Lakes } \\
\text { Wind Energy } \\
\text { Center }\end{array}$ & $\begin{array}{l}\text { Lake Erie, } \\
\mathrm{OH}\end{array}$ & $20^{*}$ & $3 \mathrm{mi}^{*}$ & $3-7^{*}$ & $\mathrm{~N}-\mathrm{A}$ & $\mathrm{N}-\mathrm{A}$ & $\begin{array}{l}\text { Completed feasibility } \\
\text { study in } 2009 \text {. Issuing } \\
\text { RFP for avian and bat } \\
\text { ecological studies. } \\
\text { Lake Erie } \\
\text { Development Corp. is } \\
\text { new developer. }\end{array}$ \\
\hline $\begin{array}{l}\text { Long Island } \\
\text { Power Authority } \\
\text { (LIPA) and } \\
\text { Florida Power and } \\
\text { Light Energy }\end{array}$ & $\begin{array}{l}\text { Long Island } \\
\text { Offshore Wind } \\
\text { Park }\end{array}$ & NY & $140^{*}$ & $\begin{array}{l}3.6 \mathrm{mi} / 50- \\
70 \mathrm{ft}^{*}\end{array}$ & $\begin{array}{l}40 \times 3.6 \mathrm{MW} \\
\text { turbines }\end{array}$ & $\mathrm{N}-\mathrm{A}$ & $\begin{array}{l}\text { Assumed to be } \\
\text { LIPA }\end{array}$ & $\begin{array}{l}\text { Project on hold; } \\
\text { application remains } \\
\text { active with MMS }\end{array}$ \\
\hline $\begin{array}{l}\text { LIPA and } \\
\text { ConEdison }\end{array}$ & $\begin{array}{l}\text { Rockaway } \\
\text { Peninsula }\end{array}$ & NY & $\begin{array}{l}\text { Phase 1: } 350 \\
\text { Phase 2: } \\
+350\end{array}$ & $\begin{array}{l}13 \mathrm{~nm} / 18- \\
37 \mathrm{~m}^{*}\end{array}$ & $167^{*}$ & 2015 & $\begin{array}{l}\text { Assumed to be } \\
\text { LIPA }\end{array}$ & $\begin{array}{l}\text { Moving forward with } \\
\text { pre-proposal data } \\
\text { collection; issuing } \\
\text { RFP for construction }\end{array}$ \\
\hline Deepwater Wind & $\begin{array}{l}\text { Deepwater Wind } \\
\text { Plum Island }\end{array}$ & $\begin{array}{l}\text { Plum Island, } \\
\text { NY }\end{array}$ & $10 \mathrm{MW}^{*}$ & $15-18 \mathrm{mi}^{*}$ & $3^{*}$ & $\mathrm{~N}-\mathrm{A}$ & N-A & $\begin{array}{l}\text { Winergy filed USACE } \\
\text { application in } 2007\end{array}$ \\
\hline $\begin{array}{l}\text { Deepwater Wind } \\
\text { (owns Winergy } \\
\text { Power) }\end{array}$ & $\begin{array}{l}\text { Deepwater Wind } \\
\text { New Jersey }\end{array}$ & Avalon, NJ & $345 \mathrm{MW}^{*}$ & $\begin{array}{l}15-20 \mathrm{mi} \text {, up } \\
\text { to } 150 \mathrm{ft}\end{array}$ & $\mathrm{N}-\mathrm{A}$ & $\mathrm{N}-\mathrm{A}$ & $\mathrm{N}-\mathrm{A}$ & $\begin{array}{l}\text { Has Interim Policy } \\
\text { Lease. Decided not to } \\
\text { pursue project. }\end{array}$ \\
\hline $\begin{array}{l}\text { NRG Bluewater } \\
\text { Wind }\end{array}$ & $\begin{array}{l}\text { NJ site } \\
\text { evaluation }\end{array}$ & $\begin{array}{l}\text { Atlantic } \\
\text { City, NJ }\end{array}$ & $350^{*}$ & $15 \mathrm{mi}$ & $\mathrm{N}-\mathrm{A}$ & $\mathrm{N}-\mathrm{A}$ & N-A & $\begin{array}{l}\text { Secured exploratory } \\
\text { MMS lease }\end{array}$ \\
\hline $\begin{array}{l}\text { Principle Power } \\
\text { Inc. and } \\
\text { Tillamook Inter- } \\
\text { governmental } \\
\text { Development } \\
\text { Agency }\end{array}$ & $\begin{array}{l}\text { OR floating } \\
\text { platform demo }\end{array}$ & $\begin{array}{l}\text { Tillamook, } \\
\text { OR }\end{array}$ & $150 \mathrm{MW}^{*}$ & $>50 \mathrm{M}$ depth & $30^{*}$ & $\mathrm{~N}-\mathrm{A}$ & $\mathrm{N}-\mathrm{A}$ & $\begin{array}{l}\text { Engineering and } \\
\text { design on offshore } \\
\text { floating deep-water } \\
\text { platforms (DOE- } \\
\text { funded) }\end{array}$ \\
\hline $\begin{array}{l}\text { BlueH } \\
\text { Technologies } \\
(\mathrm{NL}) \\
\end{array}$ & $\begin{array}{l}\text { Demonstration } \\
\text { for "Project } \\
\text { Balinda" }\end{array}$ & $\begin{array}{l}\text { MA, SE of } \\
\text { Martha's } \\
\text { Vinyard }\end{array}$ & $\sim 500 \mathrm{MW}$ & $30 \mathrm{mi}, 160 \mathrm{ft}$ & $\mathrm{N}-\mathrm{A}$ & $\mathrm{N}-\mathrm{A}$ & $\mathrm{N}-\mathrm{A}$ & $\begin{array}{l}\text { Temporary permit } \\
\text { received from USACE } \\
\text { for floating turbines }\end{array}$ \\
\hline
\end{tabular}




\begin{tabular}{|l|l|l|l|l|l|l|l|l|}
\hline $\begin{array}{l}\text { Grays Harbor } \\
\text { Ocean Energy } \\
\text { Corporation }\end{array}$ & $\begin{array}{l}\text { Grays Harbor } \\
\text { Wind/Wave }\end{array}$ & $\begin{array}{l}\text { Grays } \\
\text { Harbor, WA }\end{array}$ & $270 \mathrm{MW}^{*}$ & $2.8 \mathrm{mi}$ & N-A & N-A & N-A & $\begin{array}{l}\text { Obtained FERC demo } \\
\text { permit }\end{array}$ \\
\hline $\begin{array}{l}\text { Scandia Offshore } \\
\text { Wind }\end{array}$ & Aegis & $\begin{array}{l}\text { Mi, Lake } \\
\text { Michigan }\end{array}$ & $500 \mathrm{MW}$ & $5.5-8.7 \mathrm{~km}$ & $100-250$ & N-A & N-A & $\begin{array}{l}\text { In response to local } \\
\text { opposition, halved } \\
\text { output and footprint }\end{array}$ \\
\hline $\begin{array}{l}\text { Outer Banks } \\
\text { Offshore Energy } \\
\text { Corp }\end{array}$ & $\begin{array}{l}\text { Cape Lookout } \\
\text { Energy Preserve }\end{array}$ & NC & $200 \mathrm{MW}^{*}$ & $25 \mathrm{mi}^{*}$ & $50+^{*}$ & N-A & N-A & No recent activity \\
\hline Baryonyx Corp & $\begin{array}{l}\text { Mustang and Rio } \\
\text { Grand projects }\end{array}$ & TX & N-A & $4.25-10.3 \mathrm{mi}^{*}$ & $170-225^{*}$ & N-A & N-A & $\begin{array}{l}\text { State lease secured, } \\
\text { undergoing env'al } \\
\text { reviews/permitting }\end{array}$ \\
\hline
\end{tabular}

${ }^{*}$ Unconfirmed or updates not available; may reflect outdated information.

$\dagger \mathrm{N}-\mathrm{A}=$ Not Available. 



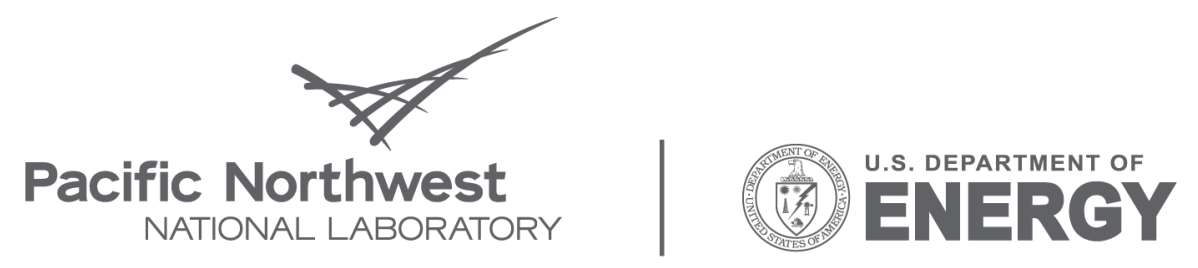

Proudly Operated by Battelle Since 1965

902 Battelle Boulevard

P.O. Box 999

Richland, WA 99352

1-888-375-PNNL (7665)

www.pnl.gov 